\title{
Functional Analysis of the Asian Soybean Rust Resistance Pathway Mediated by Rpp2
}

\author{
Ajay K. Pandey, ${ }^{1,2}$ Chunling Yang, ${ }^{2}$ Chunquan Zhang, ${ }^{2}$ Michelle A. Graham, ${ }^{3,4}$ Heidi D. Horstman, ${ }^{2}$ \\ Yeunsook Lee, ${ }^{2}$ Olga A. Zabotina, ${ }^{5}$ John H. Hill, ${ }^{2}$ Kerry F. Pedley, ${ }^{1}$ and Steven A. Whitham ${ }^{2}$ \\ ${ }^{1}$ Foreign Disease-Weed Science Research Unit, United States Department of Agriculture-Agricultural Research Service \\ (USDA-ARS), 1301 Ditto Avenue, Ft. Detrick, MD 21702, U.S.A.; ${ }^{2}$ Department of Plant Pathology, lowa State University, \\ Ames 50011, U.S.A.; ${ }^{3}$ Corn Insects and Crop Genetics Research Unit, USDA-ARS, Ames, IA 50011, U.S.A.; ${ }^{4}$ Department of \\ Agronomy and ${ }^{5}$ Department of Biochemistry, Biophysics, and Molecular Biology, lowa State University, Ames
}

Submitted 26 August 2010. Accepted 19 October 2010.

\begin{abstract}
Asian soybean rust is an aggressive foliar disease caused by the obligate biotrophic fungus Phakopsora pachyrhizi. On susceptible plants, the pathogen penetrates and colonizes leaf tissue, resulting in the formation of necrotic lesions and the development of numerous uredinia. The soybean Rpp2 gene confers resistance to specific isolates of $P$. pachyrhizi. Rpp2-mediated resistance limits the growth of the pathogen and is characterized by the formation of reddish-brown lesions and few uredinia. Using virus-induced gene silencing, we screened 140 candidate genes to identify those that play a role in $R p p 2$ resistance toward $P$. pachyrhizi. Candidate genes included putative orthologs to known defense-signaling genes, transcription factors, and genes previously found to be upregulated during the $R p p 2$ resistance response. We identified 11 genes that compromised $R p p 2$-mediated resistance when silenced, including GmEDS1, GmNPR1, GmPAD4, GmPAL1, five predicted transcription factors, an O-methyl transferase, and a cytochrome P450 monooxygenase. Together, our results provide new insight into the signaling and biochemical pathways required for resistance against $P$. pachyrhizi.
\end{abstract}

Asian soybean rust (ASR) is an aggressive foliar disease caused by the obligate biotrophic fungus, Phakopsora pachyrhizi Syd. \& P. Syd. Unlike most rust fungi, P. pachyrhizi has an unusually broad host range, infecting over 95 plant species from more than 42 genera, including soybean and related Glycine spp. (Bromfield 1984; Ono et al. 1992; Rytter et al. 1984). In regions where the pathogen is established, it can cause significant yield losses of 10 to 80\% (Bromfield 1984; Ogle et al.

The use of trade, firm, or corporation names in this publication is for the information and convenience of the reader. Such use does not constitute an official endorsement or approval by the United States Department of Agriculture or the Agricultural Research Service of any product or service to the exclusion of others that may be suitable.

Corresponding authors: S. A. Whitham; Telephone: +1.515.294.4952; Fax: +1.515.294.9420; E-mail: swhitham@iastate.edu; and K. F. Pedley; Telephone: +1.301.619.1668; Fax: +1.301.619.2880; E-mail: Kerry.Pedley@ ars.usda.gov

* The $\boldsymbol{e}$-Xtra logo stands for "electronic extra" and indicates that two supplementary tables are published online.

This article is in the public domain and not copyrightable. It may be freely reprinted with customary crediting of the source. The American Phytopathological Society, 2011.
1979; Patil et al. 1997). P. pachyrhizi was first discovered in Asia in 1902 and has since spread to all the major soybeanproducing regions of the world (Goellner et al. 2010). The discovery of ASR in the continental United States in the fall of 2004 has raised concern from U.S. soybean producers and has generated new interest in the biology and epidemiology of the disease (Li et al. 2010; Schneider et al. 2005).

Susceptible soybean plants infected with virulent isolates of $P$. pachyrhizi are characterized by tan-colored lesions and sporulating uredinia, predominantly on the abaxial leaf surfaces (tan phenotype) (Bromfield 1984; Bromfield and Hartwig 1980; Miles et al. 2006). Microscopic studies have revealed the detailed process of infection, which starts when a urediniospore on the leaf surface produces a germ tube, followed by the formation of an appressorium. In contrast to other rust fungi that gain entry into the leaf mesophyll cells via stomata, $P$. pachyrhizi penetrates directly into epidermal cells through the formation of a penetration hypha that emerges from the appressorium (Bromfield 1984; Koch et al. 1983). This penetration results in the collapse of the breached epidermal cell. As the invading hypha emerges from the collapsed cell, a primary hypha is separated from the penetration hypha by a septum and typically branches into secondary hyphae in the leaf mesophyll. Haustorial mother cells then form at the tips of the primary and secondary hyphae, giving rise to haustoria that invade living mesophyll cells. At the late stages, intense colonization of mesophyll tissue occurs and newly developed uredia originate from the uredial primordia (Koch et al. 1983).

The adapted commercial cultivars of soybean grown in the United States and abroad are susceptible to ASR. Germplasm screening and genetic analysis has led to identification of seven loci that provide varying degrees of resistance to $P$. pachyrhizi (Rpp). These seven loci are referred to as Rppl (Cheng and Chan 1968; Hartwig and Bromfield 1983; Hidayat and Somaatmadja 1977; McLean and Byth 1980), Rpplb (Ray et al. 2009), Rpp2 (Hidayat and Somaatmadja 1977), Rpp3 (Bromfield and Hartwig 1980), Rpp4 (Hartwig 1986), Rpp5 (Garcia et al. 2008), and Rpp?(Hyuuga) (Monteros et al. 2007). Rppl is unique among these genes in that it confers an immune response to particular avirulent fungal isolates for which there are no visible symptoms or uredinia formation on the leaves (Miles et al. 2006). In contrast, plants containing any of the other Rpp genes identified to date produce dark reddish-brown $(\mathrm{RB})$ lesions at the site of infection in response to avirulent isolates of the pathogen. The RB lesions are correlated with restricted fungal growth and limited sporulation on the leaf surfaces (Bonde et al. 2006; Garcia et al. 2008). 
Several approaches have been taken to investigate the effects of ASR on soybean mRNA transcript levels in compatible and incompatible interactions. A suppressive subtractive hybridization screen of Rppl plants inoculated with virulent and avirulent isolates of $P$. pachyrhizi was utilized to identify the transcripts that were differentially expressed during the immune reaction (Choi et al. 2008). Another set of studies suggested that the differential expression of soybean genes in response to a virulent ASR isolate may be related to the growth stages of the plant (Panthee et al. 2007, 2009). Molecular interactions between ASR and soybean were also assessed by gene expression profiles in resistant Rpp2 plants (PI230970) and susceptible rpp2 plants (Embrapa 48) over a time course covering 6 to $168 \mathrm{~h}$ after inoculation (hai) (van de Mortel et al. 2007). Two distinct phases of soybean gene expression occur in response to ASR infection. During the first 24 hai, a nonspecific response was identified in which differential expression of soybean genes reached a maximum in the first 12 hai in the compatible and incompatible genotypes before returning to baseline levels. A second phase of differential gene expression was observed beginning at 72 hai in the Rpp2 genotype but not until later time points in the rpp 2 genotype. The kinetics of gene expression changes suggested that race-specific recognition of the ASR isolate had occurred in Rpp 2 plants, leading to an effective defense response. Collectively, the studies related to soybean gene expression in response to $P$. pachyrhizi have led to the identification of several functional classes of genes that are upregulated during infection, including those associated with defense signaling, regulation of mRNA transcription (WRKY and MYB transcription factors) (TF), primary and secondary metabolism, and cell wall synthesis and reinforcement. Interestingly, all the studies have reported that genes involved in the phenylpropanoid biosynthetic pathway are highly upregulated during ASR infection, suggesting a role for products of this pathway in ASR defense (Choi et al. 2008; Panthee et al. 2009; van de Mortel et al. 2007).

The availability of a virus-induced gene silencing (VIGS) system for use in soybean coupled with the completed genome sequence has made it possible to functionally analyze genes that may play a role in defense against $P$. pachyrhizi (Schmutz et al. 2010; Zhang et al. 2009, 2010). VIGS has been successfully employed as a functional genomics tool for rapidly and effectively testing the functions of genes in defense responses in many plant-pathogen interactions, including soybean (Chen et al. 2009; Ekengren et al. 2003; Fradin et al. 2009; Fu et al. 2009; Kachroo et al. 2008; Liu et al. 2002; Zhang et al. 2009). Bean pod mottle virus (BPMV)-based vectors have been used successfully for sequence-specific gene silencing and for stable protein expression in soybean (Kachroo et al. 2008; Zhang and Ghabrial 2006; Zhang et al. 2009, 2010). With respect to plant-pathogen interactions, BPMV-based VIGS vectors were used to silence putative orthologs of the Arabidopsis AtRARl, AtSGT1, and AtHSP90 genes in soybean that were shown to mediate three different modes of immunity, including pathogen-associated molecular pattern-triggered, effector-triggered, and systemic acquired immunity against Pseudomonas syringae (Fu et al. 2009). BPMV-based vectors are also effective tools for studying resistance to Phakopsora pachyrhizi, because VIGS combined with genetic mapping and gene expression analyses were used to identify the gene that confers the Rpp4 resistance trait (Meyer et al. 2009).

The gene expression profiling experiments that have been conducted coupled with knowledge of genes that mediate defense signaling in other plants provides an extensive source of candidate genes to test for functions in soybean defenses to ASR. Here, we utilized a BPMV-based VIGS approach to identify genes that are necessary for Rpp2-mediated defense against ASR. The Rpp2 resistance trait was selected for these analyses based on the availability of a gene expression profiling dataset (van de Mortel et al. 2007). This gene expression information along with the sequences of soybean homologs of defense signaling genes was used to construct BPMV-based VIGS vectors targeting 140 genes potentially involved in the Rpp2-mediated defense response. The BPMV constructs were used to establish gene silencing in a soybean accession containing Rpp2 (PI2309870). The silenced plants were tested with an avirulent isolate of $P$. pachyrhizi to determine which of the genes played a role in resistance. Using this experimental approach, we have identified 11 genes that are required for Rpp2-mediated resistance against ASR.

\section{RESULTS}

Silencing of soybean orthologs of defense-related genes.

We screened BPMV VIGS constructs targeting 140 genes for their ability to compromise Rpp2-mediated resistance and identified 11 genes that resulted in loss-of-resistance phenotypes when silenced (Table 1; Supplementary Table S1). We began our screen by focusing on putative soybean orthologs of Arabidopsis genes with known roles in defense against microbial pathogens. The amino acid sequences of the candidate Arabidopsis proteins were used to conduct tblastn (Altschul et al. 1990) searches against the soybean expressed sequence tag (EST) contigs assembled by The Institute for Genome Research (TIGR). Soybean sequences with the highest levels of identity to their Arabidopsis counterparts were used to construct VIGS vectors for silencing genes in soybean plants containing Rpp2 (PI230970). If a silenced gene was required for resistance, we expected tan lesions indicative of a susceptible response to develop on silenced Rpp 2 plants following inoculation with the avirulent $P$. pachyrhizi isolate LA04-1. This would be consistent with our previous work using VIGS to compromise Rpp4-mediated resistance (Meyer et al. 2009).

Functional screening of known defense signaling genes resulted in identification of GmEDS1 (enhanced disease susceptibility 1), GmPAD4 (phytoalexin-deficient 4), and GmNPRI (nonexpresser of $P R$ genes 1 ) as essential components of Rpp2-mediated defense signaling. Silencing of these genes resulted in localized chlorotic areas and tan lesions with visible uredinia on the leaf surface, indicative of a loss of resistance (Fig. 1). Total RNA was extracted from the leaves of plants displaying the tan lesion phenotypes in order to confirm systemic infection by BPMV constructs, to test whether mRNA transcript levels of the target genes were reduced, and to quantify the growth of $P$. pachyrhizi. Reverse-transcriptase

Table 1. Eleven genes showing loss-of-resistance phenotypes when silenced in Rpp2 plants

\begin{tabular}{llc}
\hline Gene name & Gene ID & $\begin{array}{c}\text { Plants with tan } \\
\text { lesions }(\%)^{\mathbf{a}}\end{array}$ \\
\hline GmEDS1 & Glyma06g19920 & 100 \\
GmPAD4 & Glyma13g04540 & 100 \\
GmPAL1 & Glyma02g47940 & 92 \\
GmO-MT & Glyma07g05480 & 72 \\
GmCYP83E12 & Glyma03g03520 & 70 \\
GmWRKY36 & Glyma13g38630 & 50 \\
GmNPR1 & Glyma15g13320 & 50 \\
GmDBTF & Glyma01g02990 & 60 \\
GmWRKY40 & Glyma08g15210 & 41 \\
GmWRKY45 & Glyma04g39620 & 37 \\
GmMYB84 & Glyma08g04670 & 37 \\
\hline
\end{tabular}

${ }^{\text {a }}$ Percentage of plants on which tan lesions were observed at 14 days after Asian soybean rust inoculation on at least one leaf in three independent VIGS trials (four to six plants were tested per trial). 

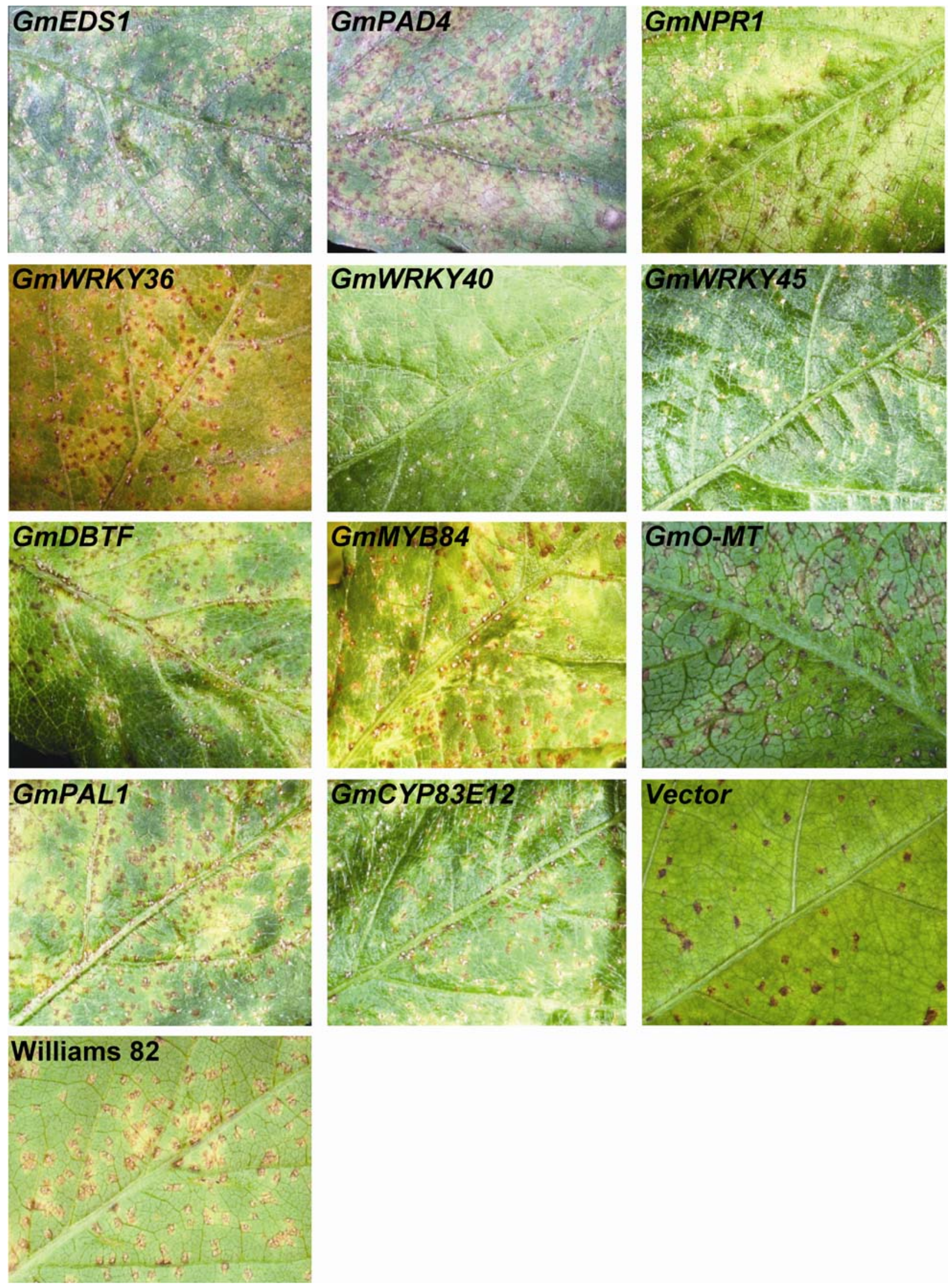

Fig. 1. Loss of Rpp2-mediated resistance to Phakopsora pachyrhizi following silencing of 11 target genes identified by a virus-induced gene silencing (VIGS) screen. Plants were infected with Bean pod mottle virus (BPMV) VIGS vectors carrying approximately 300-bp cDNA fragments corresponding to the indicated target genes. Silenced Rpp2 plants were inoculated with $P$. pachyrhizi isolate LA04-1 at 3 weeks after BPMV inoculation, and leaves were photographed 2 weeks later. Loss of resistance was observed when GmEDS1, GmPAD4, GmNPR1, GmWRKY36, GmWRKY40, GmWRKY45, GmDBTF, GmMYB84, GmO-MT, GmPAL1, and GmCYP83E12 were silenced. Vector indicates Rpp2 plants that were treated with the BPMV RNA2 without insert, which did not affect the reddish-brown lesion phenotype. Infected Williams 82 plants showing the susceptible tan phenotype served as a susceptible control. 
polymerase chain reaction (RT-PCR) using primers to detect BPMV confirmed that the virus had spread systemically in experimental and empty vector control plants (data not shown). The relative abundance of mRNA transcripts for each target

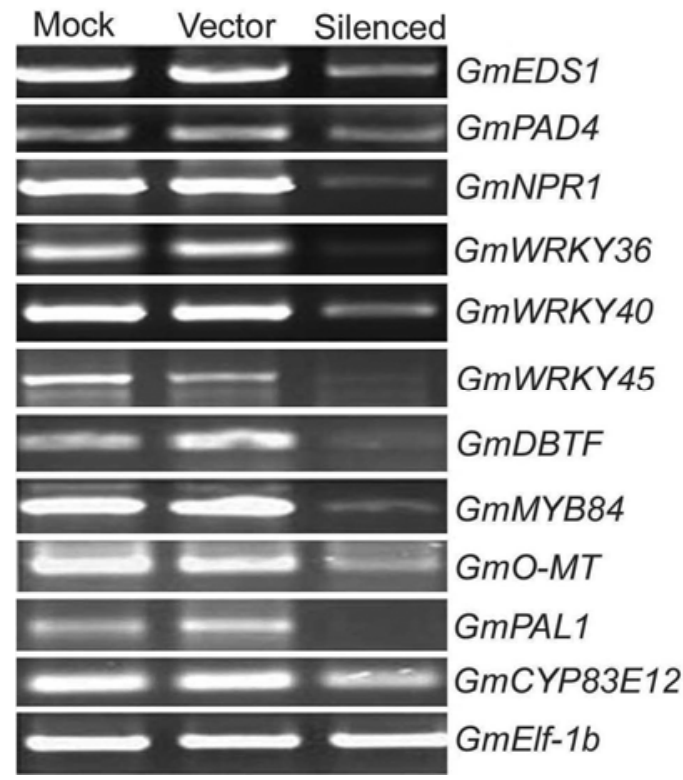

Fig. 2. Downregulation of target gene expression by Bean pod mottle virus virus-induced gene silencing in leaves with Rpp2 loss-of-resistance phenotypes. Total RNA was isolated from mock, vector control, and silenced plants at 2 weeks after Phakopsora pachyrhizi inoculation. Low-cycle reverse-transcriptase polymerase chain reaction (RT-PCR) (21 to 25 cycles) was performed using gene-specific primers, and products were separated on a $1.2 \%$ agarose gel and visualized by ethidium bromide staining. The last panel shows the Elf- $1 b$ RT-PCR product that served as a control. At least two RT-PCR reactions were performed for every gene-silenced plant, with similar results. gene was determined by low-cycle RT-PCR (Fig. 2) using primers designed to specifically amplify mRNA transcripts from each of the soybean target genes (Supplementary Table S2). In Rpp2 plants displaying a loss-of-resistance phenotype, we observed a reduction in the abundance of the mRNA transcripts of the target genes when compared with mock- or empty BPMV vector-treated plants (Fig. 2). In both mock- and empty vector-inoculated plants, the transcripts were expressed at similar levels.

Because the loss-of-resistance phenotype in the Rpp2 plants was expected to be accompanied by an increase in fungal growth, we used quantitative RT-PCR (QRT-PCR) to determine relative levels of $P$. pachyrhizi accumulation in control and VIGS-treated plants. The amount of P. pachyrhizi $\alpha$-tubulin transcript in each sample was normalized to the soybean ubiquitin gene to provide an estimate of the relative ratio of fungal mRNA to leaf mRNA in each sample. An increase in the ratio is an indicator of fungal growth (Meyer et al. 2009; van de Mortel et al. 2007). In GmEDS1- and GmPAD4silenced plants, the accumulation of $P$. pachyrhizi $\alpha$-tubulin transcript was four times higher than the vector-treated $R p p 2$ plants (Fig. 3). Similarly, the accumulation of $\alpha$-tubulin transcripts in GmNPRl-silenced plants was 2.5 times higher compared with empty vector-treated Rpp 2 plants. Collectively, these results show a correlation between the increase in fungal growth and the appearance of tan lesions in the Rpp2 genetic background, demonstrating that silencing GmEDS1, GmPAD4, and GmNPRl resulted in loss of resistance.

\section{Silencing WRKY TF}

in $R p p 2$ plants compromises disease resistance.

Previous gene expression studies of compatible and incompatible interactions between ASR and Rpp2 plants led to the identification of several different WRKY TF that were differentially regulated during infection (van de Mortel et al. 2007). The WRKY TF represent a well-established plant gene super-

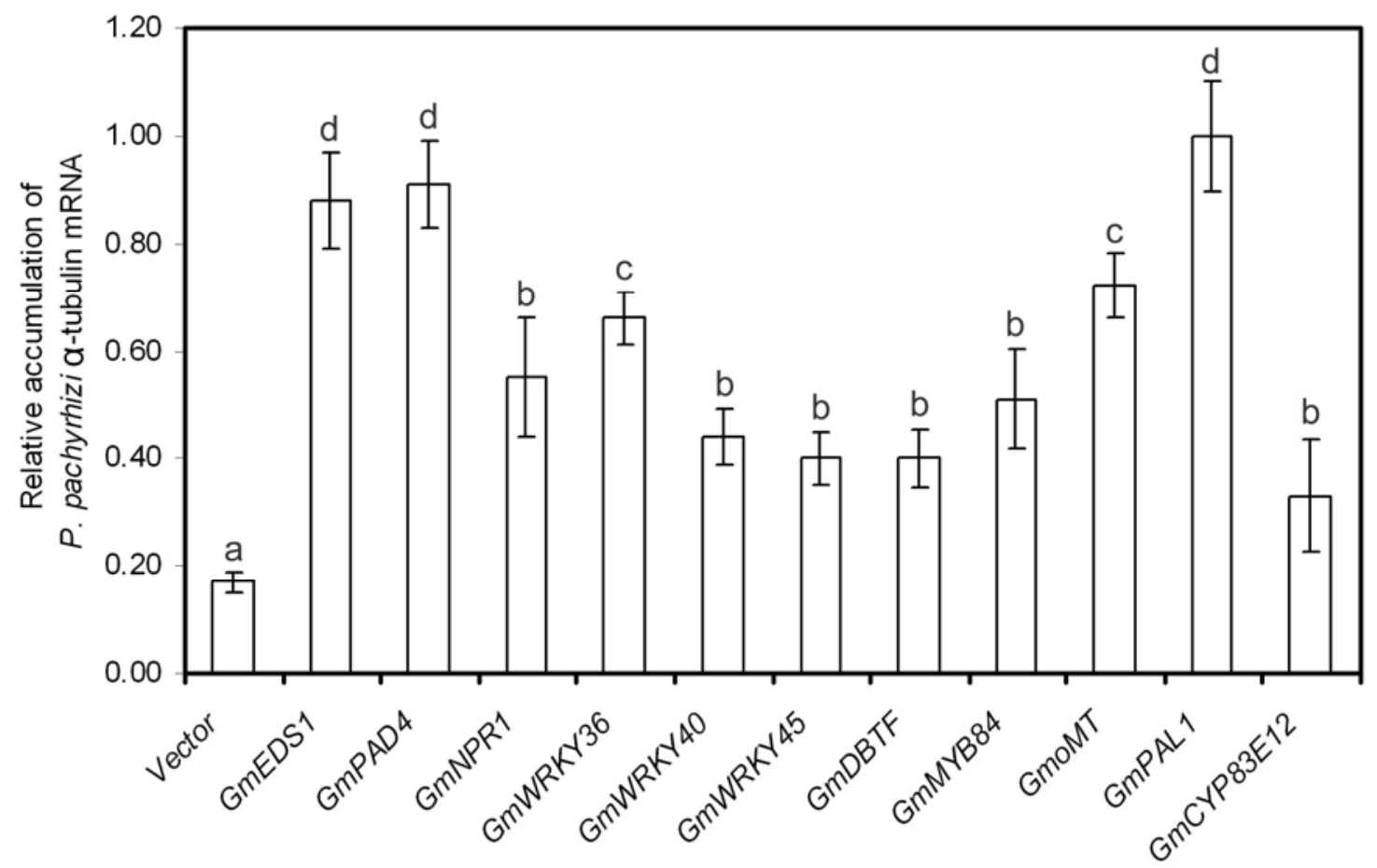

Fig. 3. Accumulation of Asian soybean rust (ASR) $\alpha$-tubulin mRNA transcripts in vector control and the virus-induced gene silencing-treated PI230970 plants that had tan lesion phenotypes. Transcript levels of Phakopsora pachyrhizi $\alpha$-tubulin in ASR-infected leaves were plotted relative to soybean ubiquitin-3 expression levels as determined by quantitative reverse-transcriptase polymerase chain reaction. Values sharing the common letters are not significantly different at $P<0.05$. 
family, and several individual WRKYs have demonstrated roles in various plant defense-signaling pathways (Rushton et al. 2010). In the current study, we silenced 64 soybean WRKY TF to test their involvement in Rpp2-mediated resistance. Here, we have used the naming conventions for soybean WRKY TF as defined by Zhou and associates (2008). The screen resulted in the identification of three WRKY TF (GmWRKY36, GmWRKY40, and GmWRKY45) which compromised Rpp2 resistance when silenced, as evidenced by the tan phenotype (Fig. 1). An additional gene, referred to in this study as
$G m D B T F$, was also selected for silencing based upon its expression profile in the previous microarray study (van de Mortel et al. 2007). Although $G m D B T F$ was previously annotated as a WRKY TF, the predicted protein lacks the signature WRKY DNA-binding domain. However, it does contain a $\mathrm{C}_{2} \mathrm{H}_{2}$ domain similar to those found in other WRKY proteins (Rushton et al. 2010; Zhou et al. 2008). Plants inoculated with BPMV constructs containing a portion of the GmDBTF gene also had compromised Rpp2 resistance (Fig. 1). Low-cycle RT-PCR analysis using gene-specific primers for the individual

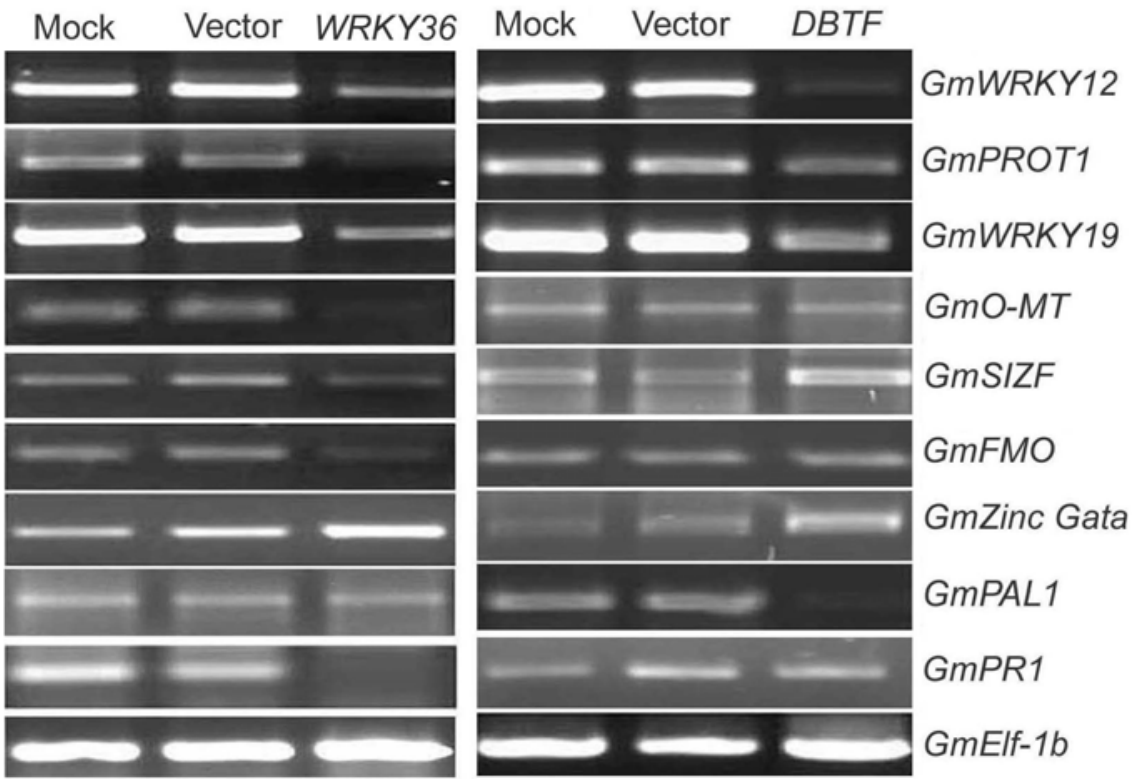

Fig. 4. Expression of genes containing W-boxes in their promoters in GmWRKY36- and GmDBTF-silenced plants. These genes were selected based on the observation that promoter sequences contained four or more W-boxes. Low-cycle reverse-transcriptase polymerase chain reaction (RT-PCR) (21 to 25 cycles) was performed using gene-specific primers, and RT-PCR products were separated on a $1.2 \%$ agarose gel and visualized by ethidium bromide staining. The last panel shows the Elf-1b RT-PCR product that served as a control. At least two RT-PCR reactions were performed for every gene-silenced plant, with similar results.

Table 2. Genes that are upregulated in Rpp2 resistance responses and have four or more W-boxes in their promoters

\begin{tabular}{llc}
\hline Gene ID $^{\mathbf{a}}$ & \multicolumn{1}{c}{ Annotated function } & W-box positions $^{\mathbf{b}}$ \\
\hline Glyma01g43420.1 & GmWRKY12 & $-23,-416,-726,-883,-974$ \\
Glyma10g34540.1 & GmPROT1 (proline transporter) & $-30,-100,-311,-815,-899$ \\
Glyma11g29720.1 & GmWRKY19 & $-76,-350,-789,-929,-964$ \\
Glyma02g39210.1 & GmSIZF (salt induced zinc finger ankyrin repeats) & $-849,-855,-897,-972$ \\
Glyma06g01110.1 & GmZincGata Zn GATA TF & $-212,-337,-434,-552$ \\
Glyma15g01990.1 & Hypothetical protein with CYC RICH DOMAIN & $-42,-228,-480,-485,-565$ \\
Glyma08g14270.1 & Hypothetical protein & $-480,-521,-806,-943$ \\
Glyma13g27060.1 & GmFMO (flavin-monooxygenase) & $-115,-174,-244,-867$ \\
Glyma07g17170.1 & GmLACBp laccase binding & $-429,-496,-599,-747,-840$ \\
Glyma04g01090.1 & GmGata (GATA TF) & $-89,-300,-415,-504,-626$ \\
Glyma02g47940.1 & GmPAL1 & $-113,-463,-741,-778$ \\
Glyma13g30570.1 & GmNUDX15 (nudix hydrolase ATNUDX15) & $-345,-869,-910,-959$ \\
Glyma02g39870.1 & GmWRKY39 & $-175,-244,-261,-528$ \\
Glyma07g09960.1 & GmCYP450 & $-195,-535,-689,-777,-822$ \\
Glyma02g16740.1 & Phenazine biosynthesis & $-4,-100,-881,-967$ \\
Glyma15g06510.1 & Oligopeptide transporter-4 & $-95,-341,-349,-924$ \\
Glyma13g00580.1 & Serine-type peptidase subtilisine like & $-81,-361,-531,-768$ \\
Glyma12g06460.1 & Zinc finger protein c3hc4 & $-32,-186,-270,-991$ \\
Glyma06g46550.1 & Strictosidine synthase & $-118,-590,-635,-670$ \\
Glyma06g47560.1 & Derlin-2, putative Rhomboid superfamily & $-108,-169,-209,-217$ \\
Glyma20g25990.1 & Hypothetical protein & $-171,-303,-401,-821$ \\
Glyma15g04160.1 & GRAS domain pyroglutamyl peptidase & $-355,-733,-745,-885$ \\
Glyma07g31700.1 & Protein kinase & $-352,-536,-579,-793$ \\
Glyma03g00830.1 & MATE efflux family protein & $-48,-257,-479,-545$ \\
Glyma15g18880.1 & Hypothetical protein (MAPEG superfamily) & $-69,-436,-518,-795$ \\
Glyma09g24170.1 & Hypothetical protein & $-69,-436,-518,-795$ \\
Glyma02g34940.1 & Hypothetical protein & $-304,-812,-822,-832$ \\
\hline Gen we &
\end{tabular}

\footnotetext{
${ }^{a}$ Genes were identified from gene expression data published by van de Mortel and associates (2007).

${ }^{\mathrm{b}}$ Nucleotide position of W-boxes with respect to the known or predicted ATG start codon.
} 
$G m W R K Y$ genes and $G m D B T F$ was performed to confirm a reduction of the targeted gene transcripts in silenced plants (Fig. 2), and levels of fungal mRNA were measured and found to correlate with the observed tan phenotypes (Fig. 3). The accumulation of fungal $\alpha$-tubulin transcripts was 1.5 to 2.0 times higher in GmDBTF-, GmWRKY40-, and GmWRKY45silenced plants compared with the empty vector control plants and 3 times higher in GmWRKY36-silenced plants.

The members of the WRKY TF superfamily are characterized by a conserved DNA-binding region known as the WRKY domain, which mediates recognition and binding to DNA elements referred to as W-boxes (C/TTGACT/C) (Pandey and Somssich 2010). Some WRKY TF regulate the expression of pathogenesis-related $(P R)$ genes (Eulgem and Somssich 2007; Eulgem et al. 2000) that often contain multiple W-boxes within their promoters (Maleck et al. 2000). GmPR1 (Glyma13g32540) was induced in Rpp2 plants when challenged with $P$. pachyrhizi (van de Mortel et al. 2007); therefore, we tested expression of $G m P R 1$ in $R p p 2$ plants silenced with $G m W R K Y 36$ or GmDBTF. Interestingly, we observed that the levels of GmPRl expression in response to isolate LA04-1 were lower in plants silenced for GmWRKY36 compared with GmDBTF and controls (Fig. 4). To further identify genes that are potentially regulated by these WRKY TF, we compiled a list of 635 unique soybean genes that were previously shown to be induced during an incompatible Rpp2-ASR interaction (van de Mortel et al. 2007). We then searched the promoter regions of these genes and identified 27 with four or more Wboxes (Table 2). The expression of a subset of these potential target genes was analyzed in the leaves of Rpp 2 plants silenced for either GmWRKY36 or GmDBTF and that displayed a tan phenotype. GmWRKY36 and GmDBTF were selected for this analysis because they showed the strongest loss-of-resistance phenotypes of the TF tested. Additionally, we also wanted to

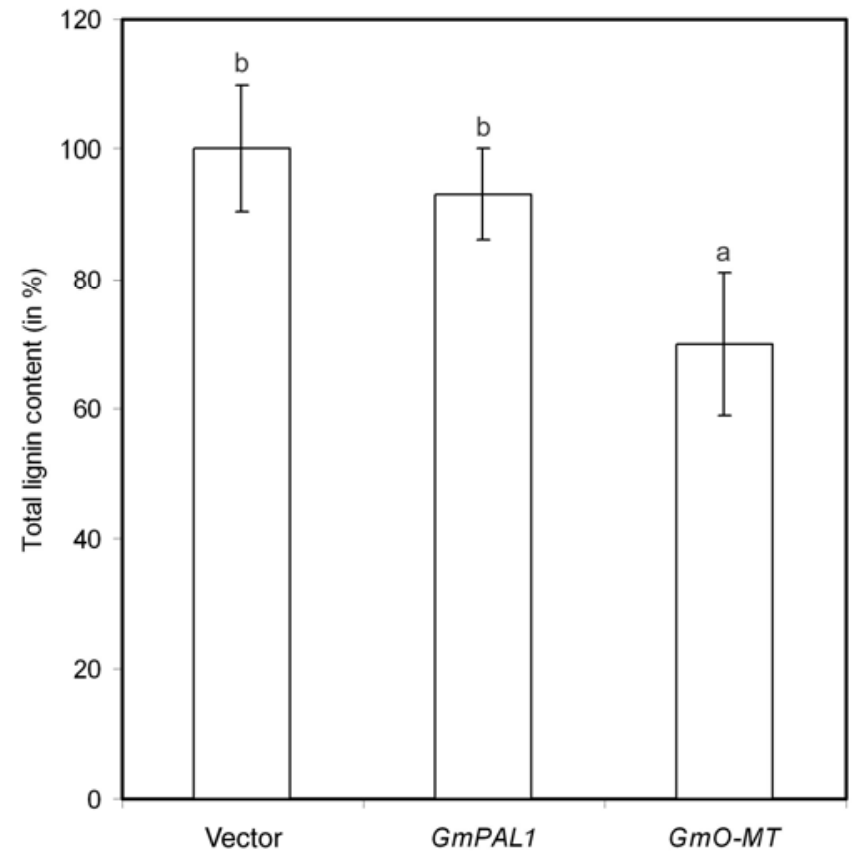

Fig. 5. Total lignin content in Rpp 2 plants in which $G m O-M T$ and GmPAL1 were silenced. The relative abundance of acetyl bromide soluble lignin in Rpp 2 plants infected with empty Bean pod mottle virus vector was set to $100 \%$ for comparison with the lignin content of leaves treated with virus-induced gene silencing constructs for silencing GmO-MT or GmPAL1. Leaves were harvested at 14 days after Phakopsora pachyrhizi inoculation, and only leaves with loss-of-resistance phenotypes were collected for the GmO-MT and GmPAL1 samples. Values sharing the common letters are not significantly different at $P<0.05$. test the putative role of $G m D B T F$ as a TF by studying genes it may regulate. The RT-PCR results showed that the expression of GmWRKY12, GmWRKY19, and GmPROT1 (proline transporter) was compromised when either GmWRKY36 or GmDBTF was silenced (Fig. 4). The expression of some of these genes was differentially affected depending on whether GmWRKY36 or $G m D B T F$ was silenced. The expression of $G m F M O$ (flavine mono-oxygenase), GmO-MT, and GmPRl was only compromised in GmWRKY36-silenced Rpp2 plants whereas the expression of GmPAL1 was only compromised in $G m D B T F$-silenced plants. These results indicate that both GmWRKY36 and GmDBTF contribute to Rpp2-mediated resistance, presumably by regulating the expression of these and other genes during ASR infection.

\section{The phenylpropanoid pathway contributes} to $R p p 2$-mediated resistance.

The phenylpropanoid pathway provides precursors for lignin biosynthesis and for the production of antimicrobial metabolites. Lignin is a complex phenolic compound produced by plants to fortify cell walls and is also produced in response to pathogens (Bhuiyan et al. 2007, 2009; Vance et al. 1980). Two key steps in the production of lignin include the conversion of phenylalanine to trans-cinnamic acid by phenylalanine ammonia lyase (PAL) and the transfer of a methyl group from caffeic acid to ferulate by o-methyltranserases (O-MT). In soybean, $G m O-M T$ and GmPALl were previously shown to be upregulated during Rpp2-mediated resistance, suggesting their possible involvement in the process of lignification (van de Mortel et al. 2007). Our low-cycle RT-PCR data for $G m O-M T$ and GmPAL1 indicated the down regulation of these genes in $G m W R K Y 36$ - and GmDBTF-silenced Rpp2 plants, respectively (Fig. 4). Based on these observations, we speculated that both GmO-MT and GmPAL1 may play a role in Rpp2-mediated resistance. We then tested the effect of silencing these genes on the phenotypic response in Rpp2 plants challenged with $P$. pachyrhizi. Our results demonstrated a loss of resistance when

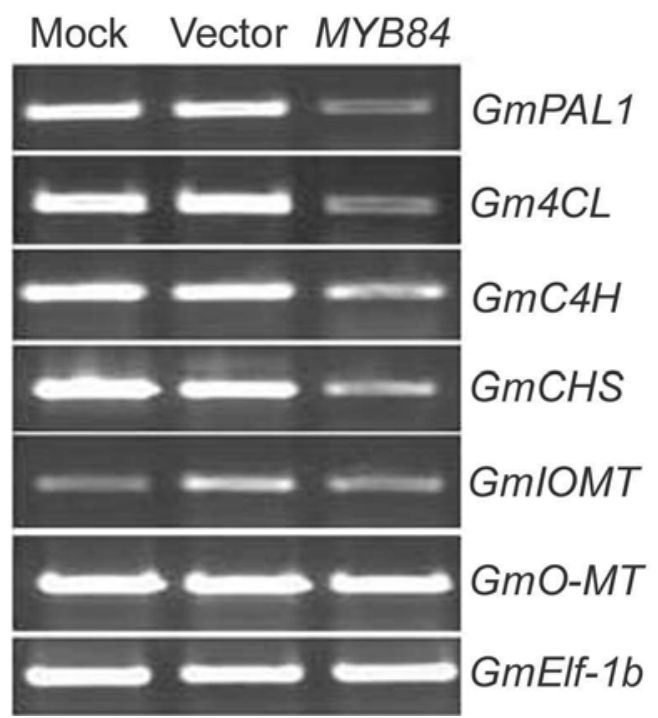

Fig. 6. Expression of phenylpropanoid pathway genes in GmMYB84silenced plants. Genes were selected based on the criteria that promoter sequences contain at least one AC element, and they are known or predicted to have roles in the phenylpropanoid pathway. Low-cycle reverse-transcriptase polymerase chain reaction (RT-PCR) (21 to 25 cycles) was performed using gene-specific primers, and RT-PCR products were separated on a $1.2 \%$ agarose gel and visualized by ethidium bromide staining. The last panel shows the Elf- $1 b$ RT-PCR product that served as a control. At least two RT-PCR reactions were performed for every gene-silenced plant, with similar results. 
either of the genes was silenced in Rpp2 plants (Fig. 1). Lowcycle RT-PCR using gene-specific primers confirmed a reduction in the transcript levels of GmO-MT and GmPAL1 in leaves showing the loss-of-resistance phenotype (Fig. 2). As expected, loss of resistance was accompanied by increased uredenia formation on the silenced leaves. QRT-PCR analysis of $P$. pachyrhizi $\alpha$-tubulin showed a fourfold increase in $G m P A L 1$-silenced leaf tissue and a threefold increase in $\mathrm{GmO}$ $M T$-silenced plants (Fig. 3). O-MT have central roles in phenylpropanoid biosynthetic pathways through their involvement in modifications of chalcone, isoflavonoids, and metabolic precursors of lignin (Ferrer et al. 2008). We detected a $30 \%$ decrease in the total lignin content in $G m O-M T$-silenced plants compared with empty vector-treated control plants (Fig. 5). These results implicate this particular soybean O-MT in lignin accumulation and indicate that lignin production is an important component of Rpp2-mediated resistance. Interestingly, no significant changes in the lignin content were observed in GmPAL1-silenced plants compared with empty vector-treated control plants.

The involvement of $G m M Y B 84$ in $R p p 2$ resistance.

Collectively, the MYB proteins compose a superfamily of $\mathrm{TF}$ involved in the regulation of several plant-specific developmental and physiological responses, including phenylpropanoid metabolism (Mehrtens et al. 2005; Stracke et. al. 2001). In the current screen, we tested VIGS constructs targeting 20 different $M Y B$ genes and, of these, silencing GmMYB84 in $R p p 2$ plants resulted in a loss-of-resistance phenotype (Fig. 1). Low-cycle RT-PCR analysis using gene-specific primers for

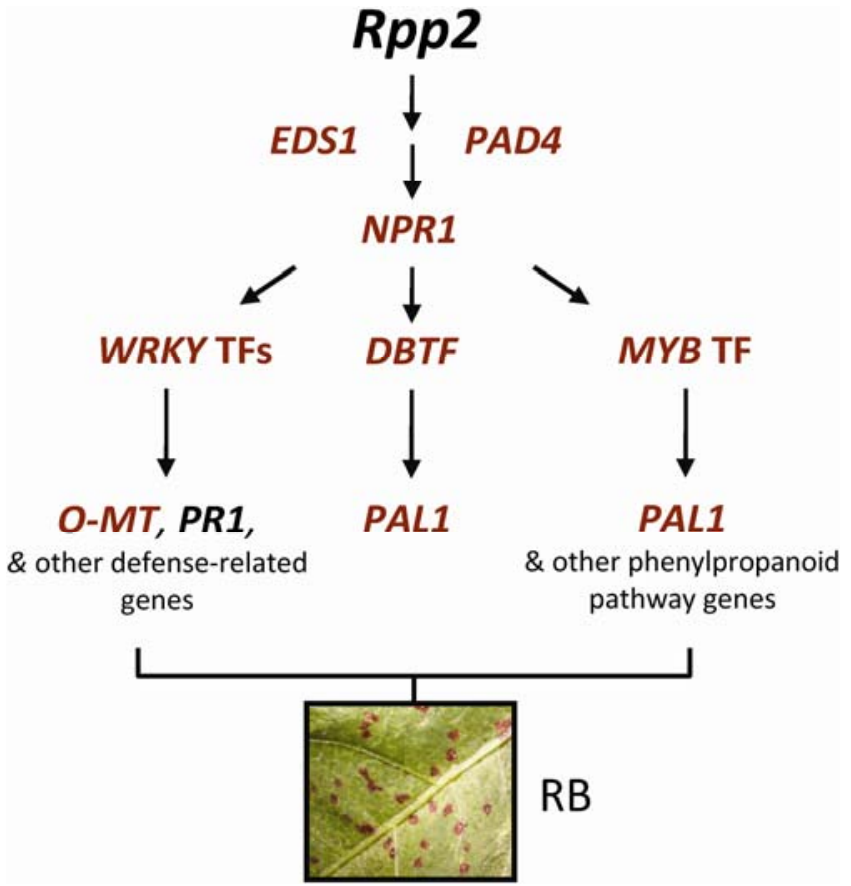

Fig. 8. Proposed framework for the Rpp2-mediated defense response. GmEDS1, GmPAD4, and GmNPR1 control the upstream defense network. GmWRKY TFs, GmDBTF, and GmMYB84 function at an intermediate level to regulate pathogenesis-related genes as well as those of the phenylpropanoid pathway. The red-brown text indicates genes that were shown by virus-induced gene silencing to be required for Rpp2 resistance.

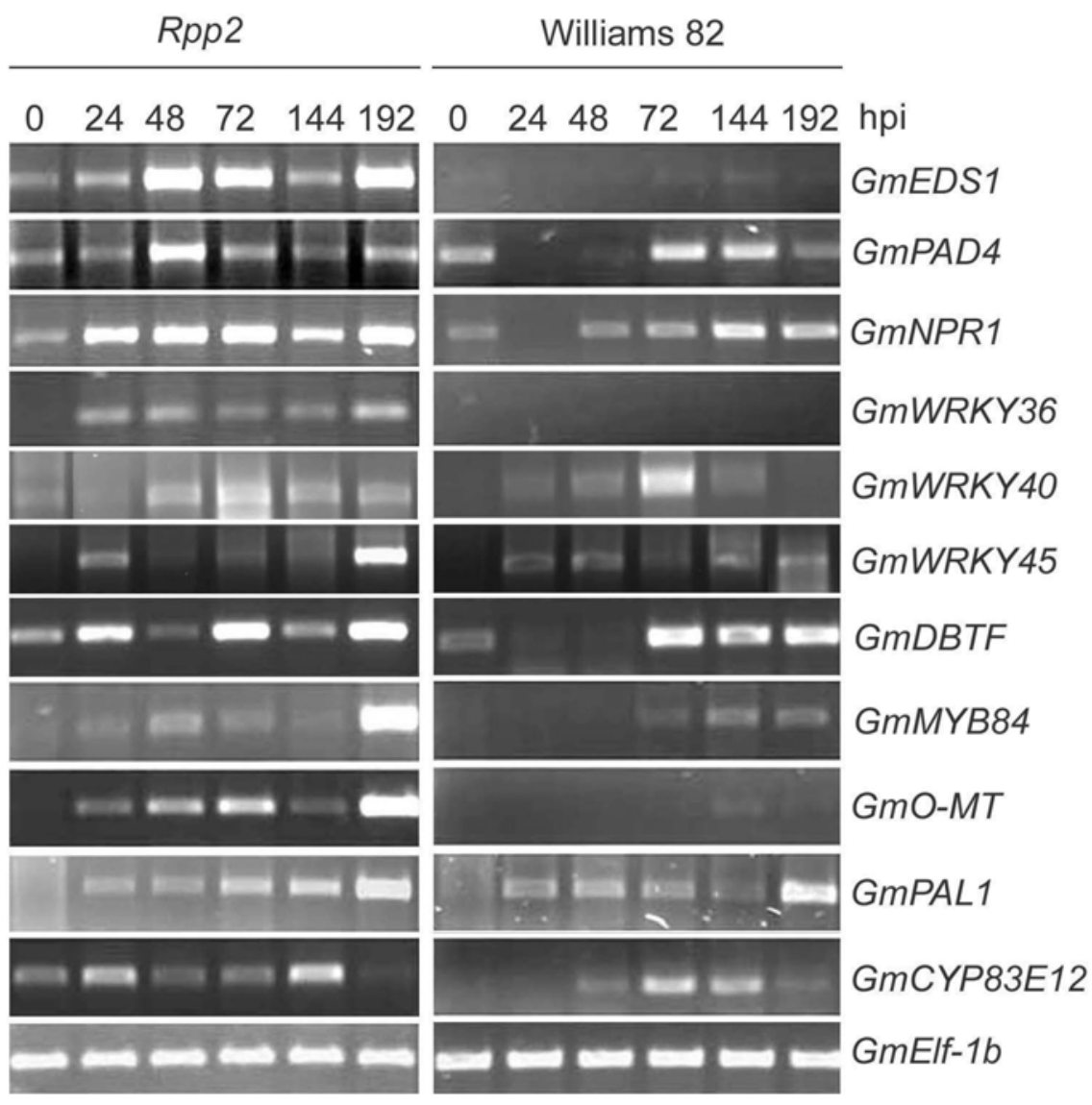

Fig. 7. Expression analysis of virus-induced gene silencing target genes that showed loss-of-resistance phenotypes following Asian soybean rust infection in PI230970 (Rpp2) and Williams82 (rpp2) plants. Total RNA was isolated from Phakopsora pachyrhizi-inoculated leaves that were collected at the time points indicated. Low-cycle reverse-transcriptase polymerase chain reaction analysis was performed for the expression analysis by using genespecific primers. 
GmMYB84 confirmed a reduction in transcript level in the VIGS plants compared with the mock and vector control plants (Fig. 2). An increase of 2.0 to 2.5 times in P. pachyrhizi $\alpha$-tubulin transcripts in leaves showing loss-of-resistance phenotypes further demonstrated that fungal growth was increased (Fig. 3).

Genes that are regulated by MYB proteins contain AC elements (-GCCTACC- and -ACCTACA-) in their promoters, and a variety of phenylpropanoid genes are regulated by these TF (Hernandez et al. 2004; Mellway et al. 2009). Phylogenetic analysis of the predicted protein sequence for GmMYB84 indicates that it belongs to the R2R3 class of MYB proteins and has a conserved DNA binding domain (data not shown). R2R3 MYB proteins from Petunia $\times$ hybrida and Vitis vinifera have been shown to play roles in the regulation of phenylpropanoid biosynthesis (Deluc et. al. 2006; Quattrocchio et al. 2006). We tested the expression of six genes that are known or predicted to be involved in the phenylpropanoid pathway using low-cycle RT-PCR. Our results showed that four of the six genes tested were downregulated in GmMYB84-silenced plants, including PAL (GmPAL1), 4-coumarate-CoA-ligase (Gm4-CL), cinnamate-4-hydroxylase $(\mathrm{GmC} 4 \mathrm{H})$, and chalcone synthase $(\mathrm{GmCHS})$ (Fig. 6). Expression levels of $G m O-M T$ and GmIOMT (isoflavone O-methyl transferase) were unaffected in GmMYB84-silenced plants. These results suggest the potential role of $G m M Y B 84$ as a regulator for some phenylpropanoid genes but not for GmO-MT or GmIOMT.

\section{Silencing of $\mathrm{GmCYP83E12}$ results in a loss-of-resistance phenotype.}

Cytochrome P450 monooxygenases (CYPP450s) mediate a wide range of oxidative reactions involved in the biosynthesis of plant secondary metabolites, including phenylpropanoid metabolism (Ferrer et al. 2008). VIGS of GmCYP83E12 in Rpp2 plants resulted in a mix of tan and RB phenotypes (Fig. 1). The mixed phenotypes could result from nonuniform silencing, or another possibility could be that this gene makes a minor contribution to Rpp2-mediated resistance. Gene-specific RT-PCR confirmed the reduction in transcript levels of this gene (Fig. 2). Quantification of P. pachyrhizi $\alpha$-tubulin demonstrated a significant increase in fungal growth (1.5 times) compared with empty vector controls (Fig. 3).

\section{Expression profiles of VIGS target genes following $P$. pachyrhizi infection.}

To determine whether the genes that compromised Rpp2mediated resistance when silenced are differentially regulated during $P$. pachyrhizi infection, we tested the mRNA expression after $0,12,24,48,72,144,192 \mathrm{~h}$ in PI230970 (Rpp2) and susceptible Williams 82 plants. Low-cycle RT-PCR was performed to evaluate the relative accumulation of the mRNA transcripts in the two genotypes after inoculation. We observed rapid induction of transcript accumulation for all the candidate genes except for GmWRKY40 and GmWRKY45 in the Rpp2 plants compared with the susceptible Williams 82 control (Fig. 7). It is possible that the changes in expression of GmWRKY40 and GmWRKY45 are outside the resolution of the low-cycle RTPCR.

\section{DISCUSSION}

Soybean resources such as the genome sequence (Schmutz et al. 2010), extensive EST collections (Shoemaker et al. 2002), and microarray expression profiling data (van de Mortel et al. 2007) were used in conjunction with an efficient VIGS tool to begin developing a genetic framework for Rpp2-based resistance against ASR. We used VIGS to test the possible roles of 140 candidate soybean genes in Rpp2-mediated resistance to ASR. The candidate genes were selected on the basis of sequence similarity to genes required for plant defenses in model plants and differential regulation as determined by DNA microarray analyses of the Rpp2-mediated resistance response to ASR (van de Mortel et al. 2007). Based on the loss-of-resistance phenotypes, we identified 11 different genes that contribute to Rpp2-based resistance (Fig. 8). When the loss-of-resistance phenotypes are considered in the context of molecular and biochemical information as well as knowledge from model plant-pathogen interactions, we can begin to develop the network of genes that mediate Rpp2 signaling and that contribute directly in ASR resistance (Fig. 8; Table 1).

The Rpp2 locus has been mapped to linkage group J but the gene has not been cloned (Silva et al. 2008). Three different clusters of putative resistance $(R)$ genes have been identified based upon the genomic sequence of susceptible cv. Williams 82. Cluster 1 encodes homologs of the $V f$ locus in apple, which encodes receptor-like leucine-rich repeat (LRR) proteins that confer resistance to apple scab; and clusters 2 and 3 encode two different families of Toll interleukin I receptor (TIR) nucleotide-binding site (NBS) LRR proteins (M. A. Graham, unpublished). Interestingly, we found that EDS1 and PAD4, which participate in both basal and R-protein-mediated resistance to various pathogens in other plant species (Aarts et al. 1998; Fradin et al. 2009; Glazebrook 2001; Parker et al. 1996; Peart et al. 2002; Xiao et al. 2005), were necessary for Rpp2 function. In most cases, $\mathrm{R}$ proteins requiring the functions of EDS1 and PAD4 belong to the TIR-NBS-LRR family (Meyers et al. 1999). EDS1 and PAD4 encode lipase/esterase-like proteins (Falk et al. 1999; Jirage et al. 1999) and function within the same defense pathways that regulate salicylic acid (SA) accumulation (Feys et al. 2001; Zhou et al. 1998).

Some $R$ genes, such as RPW8 and HRT from Arabidopsis, are dependent upon EDS1 but are independent of NPR1 (Chandra-Shekara et al. 2004; Xiao et al. 2005). Our finding that silencing GmNPRl caused a susceptible phenotype demonstrates that Rpp2 initiates an NPR1-dependent signaling pathway. This observation further suggests that SA has a role in mediating Rpp2 resistance, and it is consistent with previous studies demonstrating that EDS1 and PAD4 are involved in a defense augmentation loop that is regulated by SA (Rusterucci et al. 2001), and that NPR1 is central to SA signal transduction (Cao et al. 1997). The ability of GmNPRl to restore proper resistance responses to Arabidopsis nprl mutants shows that its function is conserved between soybean and Arabidopsis (Sandhu et al. 2009).

We used two different VIGS constructs in our efforts to silence GmNPR1. The first construct, named 1023, which was not as effective, targeted bases 756 to 1,045 of the GmNPRI open reading frame. The second construct, named NPR1-3', that was used to obtain the loss-of-function phenotypes, targeted bases 1,245 to 1,539 proximal to the $3^{\prime}$ end of the open reading frame. These results are consistent with a previous observation that target sequences near the $3^{\prime}$ end of the open reading frame are most effective in the BPMV vector (Zhang et al. 2010). For example, the $3^{\prime}$ end of the open reading frame of the GmPDS gene was more effective as a target sequence than the $5^{\prime}$ end of the open reading frame (Zhang et al. 2010). In addition, these results demonstrate that the inability of a BPMV VIGS clone to alter a phenotype does not necessarily eliminate a gene as being necessary for expression of that phenotype. Unfortunately, it was not practical to test multiple constructs for each of the 140 target genes selected for this study. Repeated GmNPRl-silencing experiments yielded the mixed $\mathrm{RB}$ and tan phenotype. This partial breakdown in resistance might also reflect the fact that utilizing VIGS does not ensure a 
uniform silencing of the targeted gene. Another possibility is that GmNPR1 may have a limited role in Rpp2-based defense signaling, although this seems unlikely.

Downstream of GmEDS1, GmPAD4, and GmNPR1 in our model of the Rpp2 resistance pathway are WRKY and MYB TF (Fig. 8). WRKY TF are plant-specific TF well known for their roles in regulating various physiological processes, including defense responses (Eulgem et al. 2000; Maleck et al. 2000). Here, we screened 64 GmWRKY TF for their roles in Rpp2-mediated resistance and, of these, constructs targeting GmWRKY36, GmWRKY40, and GmWRKY45 caused loss-ofresistance phenotypes. A potential complication with gene silencing is that genes sharing sufficient sequence identity may be unintentionally silenced (Jackson et al. 2003). A comparison of the nucleotide sequences of GmWRKY36 with GmWRKY45 and GmWRKY4O showed that they share identity of only 38 and $40 \%$, respectively, at the nucleotide level. Additionally, they do not share smaller 21- to 24-bp stretches of identity, which renders off-target silencing improbable (Xu et al. 2006). The putative ortholog of GmWRKY36 in Arabidopsis is WRKY6. AtWRKY6 regulates expression of pathogen defense-associated genes such as $P R l$, and it is involved in regulation of genes involved in senescence (Robatzek and Somssich 2002). Our results suggest a conserved role for GmWRKY36 and AtWRKY6 in pathogen defense, although this remains to be tested.

GmWRKY40 and GmWRKY45 share $84 \%$ identity at the nucleotide level, and low-cycle RT-PCR indicates that expression of both genes is reduced in the presence of either VIGS construct (data not shown). This observation demonstrates that soybean genes with at least $84 \%$ nucleotide identity can be cosilenced by the BPMV vector system. Thus, it is not possible at this time to conclude definitively whether GmWRKY40, $G m W R K Y 45$, or both are required for Rpp 2 resistance. Reduced mRNA expression of these WRKY TF resulted in robust loss-of-resistance phenotypes in Rpp2 plants. Previous work suggested that GmWRKY40 and GmWRKY45 are moderately induced when soybean is subjected to drought and salt stress (Zhou et al. 2008), suggesting a possible role in abiotic stress responses. Our results clearly show that these TF have a functional role in defense against ASR. Studies in poplar have also supported a role for WRKY TF in rust disease resistance. For example, poplar WRKY23 is involved in resistance to poplar rust by causing deregulation of genes that disrupt redox homeostasis and cell wall metabolism (Levee et al. 2009). The closest soybean homolog to Populus tremuloides WRKY23 is GmWRKY51, construct no. 70) but no phenotypic change was observed on $R p p 2$ plants treated with the corresponding VIGS construct.

We found that soybean defense responses were disrupted in GmWRKY36-silenced plants. GmPR1 was not induced in GmWRKY36-silenced plants that were infected with $P$. pachyrhizi, suggesting that it is involved in regulating expression of $\mathrm{PR}$ genes in soybean. The presence of multiple W-boxes in the promoter region of $G m P R l$ indicates that it is a potential target for GmWRKY36. Based on misexpression of GmPRl in GmWRKY36-silenced plants, we also examined the regulation of other rust-responsive genes with W-boxes in their promoters. RT-PCR analysis demonstrated that a subset of genes possessing W-boxes was regulated by GmWKRY36 while others were unaffected. Interestingly, silencing $G m D B T F$ and GmWRKY36 affected the expression of GmWRKY12, GmPROT1, and GmWRKY19. However, only GmDBTF silencing affected expression of GmPAL1, and only GmWRKY36 silencing affected expression of GmO-MT, GmSIZF, GmFMO, and GmPR1. These results suggest that GmWRKY36 and $G m D B T F$ may function cooperatively to regulate the expression of some genes and function independently of one another to regulate the expression of others. It will be interesting to further characterize the groups of genes that fall into these three regulatory classes and decipher the underlying mechanisms controlling their mRNA expression.

PAL1 catalyzes the first step of the pathway for the synthesis of phenolic phytochemicals known collectively as phenylpropanoids. Phenylpropanoid pathway genes that are induced during defense responses can play important roles in disease resistance in many plant species (Graham et al. 2007; SoriaGuerra et al. 2010). Several genes involved in the phenylpropanoid pathway, including GmPAL, were highly upregulated in Rpp2 soybean plants following ASR infection (van de Mortel et al. 2007). Furthermore, recent metabolic profiling revealed increased accumulation of isoflavonoids and flavonoids in all the resistant soybean genotypes during ASR infection when compared with susceptible genotypes (Lygin et al. 2009). $R p p 2$ plants in which GmPAL1 was silenced had a susceptible phenotype suggesting a role for phenylpropanoids in ASR defense. Interestingly, some phenolic compounds derived from the phenylpropanoid pathway inhibited germination of $P$. pachyrhizi spores (Lygin et al. 2009). Collectively, these observations point to an essential role of the phenylpropanoid pathway in Rpp2 resistance.

The process of lignification requires metabolites from a branch point in the phenylpropanoid pathway. The accumulation of lignin or lignin-like phenolics is well studied during plant defense responses (Nicholson and Hammerschmidt 1992; Vance et al. 1980). O-methyl transferases are involved in methylation of ferulic and sinapic acids, both of which are precursors for lignin biosynthesis. Silencing of GmO-MT compromised Rpp2based disease resistance, and biochemical analysis demonstrated that the total lignin content was reduced. However, no significant changes in total lignin content were observed in GmPAL1silenced leaf tissues despite showing a loss-of-resistance phenotype. This might be due to the presence of other PAL coding sequences in the soybean genome. Sequence searches revealed two additional PAL coding genes (Glyma03g338801 and Glyma10g06600), raising the possibility that each has a distinct role in phenylpropanoid metabolism. Biochemical studies of Atpall and Atpal2 mutants in Arabidopsis suggested overlapping and independent functions of these genes (Rohde et al. 2004). In Populus tremuloides, PtPALl was connected with the biosynthesis of condensed tannin and other phenolics, whereas PtPAL2 is mostly associated with lignin biosynthesis (Kao et al. 2002). These studies show that PAL1 paralogs may have distinct and overlapping functions in phenylpropanoid pathways, and suggest that further studies of the roles of specific PAL1 isoforms are warranted in soybean.

The GmO-MT transcript levels were reduced in GmWRKY36silenced plants, suggesting that $G m O-M T$ transcription is regulated by $G m W R K Y 36$. A role of this soybean WRKY in regulating expression of a lignin biosynthetic gene would be consistent with other transgenic and biochemical studies that have implicated WRKY TF in regulating lignification (Naoumkina et al. 2008). Consistent with this idea, overexpression of rice $O s W R K Y 89$ caused greater lignification and enhanced resistance to rice blast fungus (Wang et al. 2007). Our data, combined with knowledge from other studies, support the idea that upregulation of phenylpropanoid-related pathways and lignin reinforcement of cell walls are plant defense mechanisms that are critical for Rpp2-mediated disease resistance to ASR.

Another gene we identified that is required for Rpp2-based resistance is $G m C Y P 83 E 12$, which belongs to the CYP450 family of monooxygenases. CYP450s are involved in primary metabolism as well as biosynthesis of plant secondary metabolites, including phytoalexins such as those derived from phe- 
nylpropanoid precursors (Ehlting et al. 2008; Frank et al. 1996). Two CYP83 subfamily members in Arabidopsis are involved in plant defense by catalyzing reactions on aldoxime moieties that are needed for biosynthesis of aci-Nitro compounds leading to the accumulation of both thiol- and indolederived glucosinolates (Bak and Feyereisen 2001). One of the members of $C Y P 83$, AtCYP83B1, is involved in the indole pathway, which branches from the phenylpropanoid pathway. The functions of both CYP83 family members can affect flux through the phenylpropanoid pathway (Hemm et al. 2003). It is possible that GmCYP83E12 is associated with the production of antimicrobial metabolites, possibly derived from the phenylpropanoid pathway, though additional studies are needed to establish this.

The MYB TF were implicated in the regulation of genes that are involved in the phenylpropanoid pathway (Mehrtens et al. 2005; Mellway et al. 2009; Stracke et. al. 2001). These genes are notably upregulated in soybean by wounding, elicitor treatments, or challenge by various pathogens (Graham and Graham 1994, 1996; Zabala et al. 2006; Zou et al. 2005). Out of the 20 different $M Y B$ genes we tested, only the VIGS construct targeting GmMYB84 compromised Rpp2-mediated resistance. Phylogenetic analysis for the predicted $G m \mathrm{MYB} 84$ protein sequence showed that it belongs to the R2R3 class of MYB proteins and has high similarity to the Petunia PH4 protein, which is involved in anthocyanin synthesis (Quattrocchio et al. 2006). MYB TF are known to regulate phenylpropanoid genes by binding to $\mathrm{AC}$ elements in their promoter regions (Hernandez et al. 2004). Based on this information, we hypothesized that GmMYB84 might act as regulator of genes in the phenylpropanoid pathway. We demonstrated that expression of GmPAL1, Gm4-CL, GmC4H, and GmCHS genes was affected in GmMYB84-silenced Rpp2 plants, which supported our hypothesis. Consistent with the silencing results, these genes have at least one $\mathrm{AC}$ element in their promoter sequences, providing further evidence that they could be potential targets for GmMYB84. However, the regulation of GmPAL1 is expected to be complex, given that $G m D B T F$ also was necessary for its expression. At this time, we do not know whether GmMYB84 and $G m D B T F$ act in concert or independently to regulate GmPAL1 expression; therefore, we have indicated their roles in regulation of $R p p 2$ resistance in parallel in Figure 8. Furthermore, a role for $G m D B T F$ in expression of other phenylpropanoid pathway genes dependent upon GmMYB84 was not tested.

In conclusion, our results show that there is significant interplay between members of soybean TF families in controlling genes that are necessary for resistance to ASR. This study is a step toward establishing the genetic and biochemical hierarchies that regulate and mediate ASR resistance in soybean. The Rpp2 resistance pathway model that was developed also builds upon knowledge available from model plant systems but many gaps remain. For example, AtNPR1 interacts with TGA TF in Arabidopsis, which is necessary for activating defense responses (Fan and Dong 2002); however, at this time, we have not identified a member of the TGA TF family that participates in Rpp2-mediated resistance. This Rpp 2 pathway model, combining data from soybean and model plants, has allowed us to develop some interesting new hypotheses to explore in order to better understand soybean disease defense pathways.

\section{MATERIALS AND METHODS}

\section{BPMV VIGS constructs}

and $\operatorname{Rpp} 2$ loss-of-resistance screening.

PCR products were amplified from corresponding EST clones or genomic DNA and were then cloned into RNA2 of the BPMV VIGS vector (Zhang et al. 2009). The orientation and identity of the VIGS inserts were confirmed by sequencing using a vector-specific forward primer 1548F (Zhang et al. 2009). To generate inoculum for the VIGS experiments, BPMV RNA1 (pBPMV-IA-R1M) and the recombinant RNA2 DNA clones were co-inoculated by gold particle bombardment on leaves of Williams82 plants at 14 days after sowing, as previously described (Zhang et al. 2009, 2010). BPMV-infected leaf tissue was collected at 3 to 5 weeks after bombardment, lyophilized, and stored at $-20^{\circ} \mathrm{C}$.

Seed of PI2130970 (Rpp2) were germinated in a growth chamber and, 2 weeks later, the primary leaves of four to six seedlings were dusted with Carborundum and subsequently rub inoculated with lyophilized leaf tissue corresponding to each VIGS construct suspended in $50 \mathrm{mM}$ potassium phosphate buffer, $\mathrm{pH}$ 7.0. BPMV-inoculated plants were maintained in the growth chamber at $20^{\circ} \mathrm{C}$ with a 16 -h photoperiod. Three weeks following BPMV infection, plants were transferred to the United States Department of Agriculture Plant Pathogen BSL-3 containment facility at Fort Detrick (Melching et al. 1983). The plants were inoculated with $1.1 \times 10^{5}$ spores of $P$ pachyrhizi isolate LA04-1 resuspended in sterile water containing $0.5 \%$ Tween-20 and then placed in a dew chamber overnight. Plants were then moved to a greenhouse and evaluated for resistant (RB lesions) and susceptible (tan lesions) phenotypes at 2 weeks after inoculation with $P$. pachyrhizi. In addition to the BPMV vector-inoculated plants, controls included mock-inoculated plants (the same experimental conditions as the VIGS-treated plants but rub inoculated with buffer instead of the BPMV inoculum), plants that were inoculated with a BPMV vector lacking an insert, and plants that were not treated prior to inoculation with $P$. pachyrhizi. All of the control plants were infected with $P$. pachyrhizi as described for the experimental plants. For each candidate gene that resulted in a loss of resistance, three independent replicates of the experiments were performed to ensure that phenotypes were consistent.

\section{Tissue collection, total RNA isolation, and RT-PCR analysis.}

The third and fourth trifoliolate leaves of four plants were collected from mock, empty vector, and silenced leaves at 2 weeks after $P$. pachyrhizi inoculation. The leaves were immediately frozen in liquid nitrogen and stored at $-80^{\circ} \mathrm{C}$. Leaf tissue was ground in liquid nitrogen, and RNA was extracted using $4 \mathrm{ml}$ of Trizol reagent (Invitrogen, Carlsbad, CA, U.S.A.). RNA was precipitated with 2-propanol and the RNA was dissolved in $50 \mu \mathrm{l}$ of diethyl pyrocarbonate-treated water containing RNAseOUT (2 U/ $\mu$ l) (Invitrogen) and stored at $-80^{\circ} \mathrm{C}$. All RNA samples were treated with RNase-free DNase at $37^{\circ} \mathrm{C}$ for 30 min using the DNAfree kit (Ambion, Austin, TX, U.S.A.) in order to ensure the presence of only RNA amplicons prior to cDNA synthesis. First-strand cDNA synthesis was performed with $2 \mu \mathrm{g}$ of RNA and the Transcriptor first strand cDNA synthesis kit (Roche, Indianapolis, IN, U.S.A.). To test the silencing of the respective genes, low-cycle RTPCR (21 to 25 cycles) was performed with gene-specific primers. Elongation factor 1b (Elf-1b; Glyma02g44460) was included as an internal control for each set of PCR reactions.

\section{Assessment of fungal mRNA accumulation.}

Fungal growth was assessed by quantifying the constitutively expressed ASR $\alpha$-tubulin gene by TaqMan QRT-PCR (Meyer et al. 2009; van de Mortel et al. 2007). DNA-free RNA $(2 \mu \mathrm{g})$ was used for the cDNA synthesis using the Transcriptor first-strand cDNA synthesis kit RT-PCR (Roche). PCR cycling at $95^{\circ} \mathrm{C}$ for $10 \mathrm{~s}$ and data collection for $30 \mathrm{~s}$ at the extension 
temperature of $60^{\circ} \mathrm{C}$ for 45 cycles was performed. Expression data were normalized to the soybean Ubiquitin-3 gene (GenBank accession number gi 456713, dbj D28123.1), which showed no evidence for differential expression following ASR infection (van de Mortel et al. 2007).

\section{Determination of acetyl bromide soluble lignin content.}

Plant material was homogenized in $80 \%$ ( $\mathrm{vol} / \mathrm{vol})$ ethanol, heated for $1 \mathrm{~h}$ at $80^{\circ} \mathrm{C}$, and then centrifuged at $12,000 \times g$ for $30 \mathrm{~min}$. The pellet was resuspended in $80 \%$ ethanol and additionally homogenized using a Polytron Homogenizer (Fisher, Pittsburgh, PA, U.S.A.) at high speed for 2 to 3 minutes, and the procedure was repeated. The alcohol-insoluble pellet (AIS) was washed three times with $85 \%$ acetone and air dried. The dry AIS was suspended in $0.5 \%$ aqueous sodium dodecyl sulfate overnight, and the residue was recovered and washed with water by filtration, washed with a 1:1 mixture of chloroform and methanol, rinsed with acetone, and air-dried. Starch was removed by incubation with $\alpha$-amylase (Type IIA; SigmaAldrich, St. Louis) for $48 \mathrm{~h}$ at $30^{\circ} \mathrm{C}$. The remaining cell wall material (CWM) was washed with $100 \%$ acetone, air dried, and used for analyses. Acetyl bromide soluble lignin (ABSL) in soybean samples was determined according to Fukushima and Hartfield (2004). CWM (1 mg) were placed in glass vials and $100 \mu \mathrm{l}$ of freshly prepared $25 \%$ ( $\mathrm{vol} / \mathrm{vol}$ ) acetyl bromide was added. Samples were incubated at $50^{\circ} \mathrm{C}$ for $2 \mathrm{~h}$, with occasional mixing. After cooling, $400 \mu \mathrm{l}$ of $2 \mathrm{M}$ sodium hydroxide and $70 \mu \mathrm{l}$ of freshly prepared $0.5 \mathrm{M}$ hydroxylamine hydrochloride were added and, after shaking, the volume was brought to $2 \mathrm{ml}$ with acetic acid and mixed again by inversion. The solution $(200 \mu \mathrm{l})$ was pipetted into a UV-specific 96-well plate and read in a microplate reader at $280 \mathrm{~nm}$ against the blank, which contained all reagents except the CWM. The specific absorption coefficient (SAC), $20 \mathrm{~g}^{-1} \mathrm{~cm}^{-1}$, was earlier reported for purified $\mathrm{HCl}$-dioxane lignin from soybean (Lygin et al. 2009). ABSL concentration was determined using the following equation: percent lignin content $=$ (absorbance $\times$ $100) /$ SAC $\times$ sample concentration $\left(\mathrm{g}^{-1}\right) \times 0.7 \mathrm{~cm}$ (Sasaki et al. 1996), where $0.7 \mathrm{~cm}$ represents the path length of the light.

\section{ACKNOWLEDGMENTS}

This work was supported by grants from the NSF Plant Genome Research Program (award number 0820642), the Iowa Soybean Association, the United Soybean Board, and the North Central Soybean Association. This journal paper of the Iowa Agriculture and Home Economics Experiment Station, Ames, IA, project no. 3608, was supported, in part, by Hatch Act and State of Iowa Funds. We thank A. Ruck, A. E. Luquette, and J. Dittman for their excellent technical assistance.

\section{LITERATURE CITED}

Aarts, N., Metz, M., Holub, E., Staskawicz, B. J., Daniels, M. J., and Parker, J. E. 1998. Different requirements for EDS1 and NDR1 by disease resistance genes define at least two $\mathrm{R}$ gene-mediated signaling pathways in Arabidopsis. Proc. Natl. Acad. Sci. U.S.A. 18:1030610311.

Altschul, S. F., Gish, W., Miller, W., Myers, E. W., and Lipman, D. J. 1990. A basic local alignment search tool. J. Mol. Biol. 215:403-410.

Bak, S., and Feyereisen, R. 2001. The involvement of two P450 Enzymes, CYP83B1 and CYP83A1, in auxin homeostasis and glucosinolate biosynthesis. Plant Physiol. 127:108-118.

Bhuiyan, N. H., Liu, W., Liu, G., Selvaraj, G., Wei, Y., and King, J. 2007. Transcriptional regulation of genes involved in the pathways of biosynthesis and supply of methyl units in response to powdery mildew attack and abiotic stresses in wheat. Plant Mol. Biol. 64:305-318.

Bhuiyan, N. H., Selvaraj, G., Wei, Y., and King, J. 2009. Gene expression profiling and silencing reveal that monolignol biosynthesis plays a critical role in penetration defence in wheat against powdery mildew invasion. J. Exp. Bot. 60:509-521.

Bonde, M. R., Nester, S. E., Austin, C. N., Stone, C. L., Frederick, R. D.,
Hartman, G. L., and Miles, M. R. 2006. Evaluation of virulence of Phakopsora pachyrhizi and P. meibomiae isolates. Plant Dis. 90:708-716.

Bromfield, K. R. 1984. Soybean Rust, Monograph No. 11. American Phytopathological Society, St. Paul, MN, U.S.A.

Bromfield, K. R., and Hartwig, E. E. 1980. Resistance to soybean rust and mode of inheritance. Crop Sci. 20:254-255.

Cao, H., Glazebrook, J., Clarke, J. D., Volko, S., and Dong, X. 1997. The Arabidopsis NPR1 gene that controls systemic acquired resistance encodes a novel protein containing ankyrin repeats. Cell 88:57-63.

Chandra-Shekara, A. C., Navarre, D., Kachroo, A., Kang, H. G., Klessig, D., and Kachroo, P. 2004. Signaling requirements and role of salicylic acid in $H R T$ - and rrt-mediated resistance to Turnip crinkle virus in Arabidopsis. Plant J. 40:647-659.

Chen, Y. Y., Lin, Y. M., Chao, T. C., Wang, J. F., Liu, A. C., Ho, F. I., and Cheng, C. P. 2009. Virus-induced gene silencing reveals the involvement of ethylene-, salicylic acid- and mitogen-activated protein kinaserelated defense pathways in the resistance of tomato to bacterial wilt. Plant Physiol. 136:324-335.

Cheng, Y. W., and Chan, K. L. 1968. The breeding of rust resistant soybean Tainung 3. J. Taiwan Agric. Res. 17:30-34.

Choi, J. J., Alkharouf, N. W., Schneider, K. T., Matthews, B. F., and Frederick, R. D. 2008. Expression patterns in soybean resistant to Phakopsora pachyrhizi reveal the importance of peroxidases and lipoxygenases. Funct. Integr. Genomics 8:341-359.

Deluc, L., Barrieu, F., Marchive, C., Lauvergeat, V., Decendit, A., Richard, T., Carde, J. P., Mérillon, J. M., and Hamdi, S. 2004. Characterization of a grapevine R2R3-MYB transcription factor that regulates the phenylpropanoid pathway. J. Biol. Chem. 12:48205-48213.

Ehlting, J., Sauveplane, V., Olry, A., Ginglinger, J. F., Provart, N. J., and Werck-Reichhart, D. 2008. An extensive (co-)expression analysis tool for the cytochrome P450 superfamily in Arabidopsis thaliana. BMC Plant Biol. 23:8-47.

Ekengren, S. K., Liu, Y., Schiff, M., Dinesh-Kumar, S. P., and Martin, G. B. 2003. Two MAPK cascades, NPR1, and TGA transcription factors play a role in Pto-mediated disease resistance in tomato. Plant J. 36:905-917.

Eulgem, T., and Somssich, I. E. 2007. Networks of WRKY transcription factors in defense signaling. Curr. Opin. Plant Biol. 10:366-371.

Eulgem, T., Rushton, P. J., Robatzek, S., and Somssich, I. E. 2000. The $W R K Y$ superfamily of plant transcription factors. Trends Plant Sci 5:199-206.

Falk, A., Feys, B. J., Frost, L. N., Jones, J. D., and Daniels, M. J. 1999 $E D S 1$, an essential component of $R$ gene-mediated disease resistance in Arabidopsis has homology to eukaryotic lipases. Proc. Natl. Acad. Sci. U.S.A. 96:3292-3297.

Fan, W., and Dong, X. 2002. In vivo interaction between NPR1 and transcription factor TGA2 leads to salicylic acid-mediated gene activation in Arabidopsis. Plant Cell 14:1377-1389.

Ferrer, J. L., Austin, M. B., Stewart, C., Jr., and Noel, J. P. 2008. Structure and function of enzymes involved in the biosynthesis of phenylpropanoids. Plant Physiol. Biochem. 46:356-370.

Feys, B. J., Moisan, L. J., Newman, M. A., and Parker, J. E. 2001. Direct interaction between the Arabidopsis disease resistance signaling proteins, EDS1 and PAD4. EMBO (Eur. Mol. Biol. Organ.) J. 20:54005411.

Fradin, E. F., Zhang, Z., Juarez Ayala, J. C., Castroverde, C. D., Nazar, R. N., Robb, J., Liu, C. M., and Thomma, B. P. 2009. Genetic dissection of Verticillium wilt resistance mediated by tomato Ve1. Plant Physiol. 150:320-332

Frank, M. R., Deyneka, J. M., and Schuler, M. A.1996. Cloning of woundinduced cytochrome P450 monooxygenases expressed in pea. Plant Physiol. 110:1035-1046.

Fu, D. Q., Ghabrial, S., and Kachroo, A. 2009. GmRAR1 and GmSGT1 are required for basal, $\mathrm{R}$ gene-mediated and systemic acquired resistance in soybean. Mol. Plant-Microbe Interact. 22:86-95.

Fukushima, R. S., and Hatfield, R. D. 2004. Comparison of the acetyl bromide spectrophotometeric method with other analytical lignin methods for determining lignin concentration in forage samples. J. Agric. Food Chem. 52:3713-3720.

Garcia, A., Calvo, E. S., de Souza Kiihl, R. A., Harada, A., Hiromoto, D. M., and Vieira, L. G. 2008. Molecular mapping of soybean rust (Phakopsora pachyrhizi) resistance genes: Discovery of a novel locus and alleles. Theor. Appl. Genet. 117:545-553.

Glazebrook, J. 2001. Genes controlling expression of defense responses in Arabidopsis - status. Curr. Opin. Plant Biol. 4:301-308.

Goellner, K., Loehrer, M., Langenbach, C., Conrath, U., Koch, E., and Schaffrath, U. 2010. Phakopsora pachyrhizi, the causal agent of Asian soybean rust. Mol. Plant Pathol. 11:169-177.

Graham, M. Y., and Graham, T. L. 1994. Wound-associated competency factors are required for the proximal cell responses of soybean to the 
Phytophthora sojae wall glucan elicitor. Plant Physiol. 105:571-578.

Graham, T. L., and Graham, M. Y. 1996. Signaling in soybean phenylpropanoid responses (dissection of primary, secondary, and conditioning effects of light, wounding, and elicitor treatments). Plant Physiol. 110:1123-1133.

Graham, T. L., Graham, M. Y., Subramanian, S., and Yu, O. 2007. RNAi silencing of genes for elicitation or biosynthesis of 5-deoxyisoflavonoids suppresses race-specific resistance and hypersensitive cell death in Phytophthora sojae infected tissues. Plant Physiol. 144:728-740.

Hartwig, E. E. 1986. Identification of a fourth major gene conferring resistance to soybean rust. Crop Sci. 26:1135-1136.

Hartwig, E. E., and Bromfield, K. R. 1983. Relationships among three genes conferring specific resistance to rust in soybeans. Crop Sci. 23:237-239.

Hemm, M. R., Ruegger, M. O., and Chapple, C. 2003. The Arabidopsis ref2 mutant is defective in the gene encoding CYP83A1 and shows both phenylpropanoid and glucosinolate phenotypes. Plant Cell 15:179-194.

Hernandez, J. M., Heine, G. F., Irani, N. G., Feller, A., Kim, M. G. Matulnik, T., Chandler, V. L., and Grotewold, E. 2004. Different mechanisms participate in the R-dependent activity of the R2R3 MYB transcription factor C1. J. Biol. Chem. 12:48205-48213.

Hidayat, O. O., and Somaatmadja, S. 1977. Screening of soybean breeding lines for resistance to soybean rust (Phakopsora pachyrhizi Sydow). Soybean Rust Newsl. 1:9-22.

Jackson, A. L., Bartz, S. R., Schelter, J., Kobayashi, S. V., Burchard, J., Mao, M., Li, B., Cavet, G., and Linsley, P. S. 2003. Expression profiling reveals off-target gene regulation by RNAi. Nat. Biotechnol. 21:635637.

Jirage, D., Tootle, T. L., Reuber, T. L., Frost, L. N., and Feys, B. J. 1999. Arabidopsis thaliana GM-PAD4 encodes a lipase-like gene that is important for salicylic acid signaling. Proc. Natl. Acad. Sci. U.S.A. 96:13583-13588.

Kachroo, A., Fu, D. Q., Havens, W., Navarre, D., Kachroo, P., and Ghabrial, S. A. 2008. An oleic acid-mediated pathway induces constitutive defense signaling and enhanced resistance to multiple pathogens in soybean. Mol. Plant-Microbe Interact. 21:564-575.

Kao, Y.-Y., Harding, S. A., and Tsai, C.-J. 2002. Differential expression of two distinct phenylalanine ammonia-lyase genes in condensed tanninaccumulating and lignifying cells of quaking aspen. Plant Physiol. 130:796-807.

Koch, E., Ebrahim-Nesbat., F., and Hoppe, H. H. 1983. Light and electronmicroscopic studies on the development of soybean rust (Phakopsora pachyrhizi Syd) in susceptible soybean leaves. Phytopathol. Z. 106:302320

Levée, V., Major, I., Levasseur, C., Tremblay, L., MacKay, J., and Séguin, A. 2009. Expression profiling and functional analysis of Populus WRKY23 reveals a regulatory role in defense. New Phytol. 184:48-70.

Li, X., Esker, P. D., Pan, Z., Dias, A. P., Xue, L., and Yang, X. B. 2010. The uniqueness of the soybean rust pathosystem: An improved understanding of the risk in different regions of the world. Plant Dis. 94:796808

Liu, Y., Schiff, M., Marathe, R., and Dinesh-Kumar, S. P. 2002. Tobacco Rarl, EDS1 and NPRI/NIM1-like genes are required for $N$-mediated resistance to Tobacco mosaic virus. Plant J. 30:415-429.

Lygin, A. V., Li, S., Vittal, R., Widholm, J. M., Hartman, G. L., and Lozovaya, V. V. 2009. The importance of phenolic metabolism to limit the growth of Phakopsora pachyrhizi. Phytopathology 99:1412-1420.

Maleck, K., Levine, A., Eulgem, T., Morgan, A., Schmid, J., Lawton, K. A., Dangl, J. L., and Dietrich, R. A. 2000. The transcriptome of Arabidopsis thaliana during systemic acquired resistance. Nat. Genet. 26:403-410.

McLean, R. J., and Byth, D. E. 1980. Inheritance of resistance to rust (Phakopsora pachyrhizi) in soybean. Aust. J. Agric. Res. 31:951-956.

Mehrtens, F., Kranz, H., Bednarek, P., and Weisshaar, B. 2005. The Arabidopsis transcription factor MYB12 is a flavonol-specific regulator of phenylpropanoid biosynthesis. Plant Physiol. 138:1083-1096.

Melching, J. S., Bromfield, K. R., and Kingsolver, C. H. 1983. The plant pathogen containment facility at Frederick, Maryland. Plant Dis. 67:717-722.

Mellway, R. D., Tran, L. T., Prouse, M. B., Campbell, M. M., and Constabel, C. P. 2009. The wound-, pathogen-, and ultraviolet Bresponsive $M Y B 134$ gene encodes an R2R3 MYB transcription factor that regulates proanthocyanidin synthesis in poplar. Plant Physiol. 150:924-941

Meyer, J. D., Silva, D. C., Yang, C., Pedley, K. F., Zhang, C., van de Mortel, M., Hill, J. H., Shoemaker, R. C., Abdelnoor, R. V., Whitham, S. A., and Graham, M. A. 2009. Identification and analyses of candidate genes for Rpp4-mediated resistance to Asian soybean rust in soybean. Plant Physiol. 150:295-307.

Meyers, B. C., Dickerman, A. W., Michelmore, R. W., Sivaramakrishnan,
S., Sobral, B. W., and Young, N. D. 1999. Plant disease resistance genes encode members of an ancient and diverse protein family within the nucleotide-binding superfamily. Plant J. 20:317-332.

Miles, M., Frederick, R., and Hartman, G. 2006. Evaluation of soybean germplasm for resistance to Phakopsora pachyrhizi. Plant Health Prog. 10:doi/10.1094/PHP-2006-0104-01-RS.

Monteros, M. J., Missaoui, A. M., Phillips, D. V., Walker, D. R., and Boerma, H. R. 2007. Mapping and confirmation of the 'Hyuuga' redbrown lesion resistance gene for Asian soybean rust. Crop Sci. 47:829834.

Naoumkina, M. A., He, X., and Dixon, R. A. 2008. Elicitor-induced transcription factors for metabolic reprogramming of secondary metabolism in Medicago truncatula. BMC Plant Biol. 8:132-146.

Nicholson, R. L., and Hammerschmidt, R. 1992. Phenolic compounds and their role in disease resistance. Annu. Rev. Phytopathol. 30:369-389.

Ogle, H. J., Byth, D. E., and McLean, R. 1979. Effect of rust (Phakopsora pachyrhizi) on soybean yield and quality in south-eastern Queensland. Aust. J. Agric. Res. 30:883-893.

Ono, Y., Buritica, P., and Henmen, J. F. 1992. Delimitation of Phakopsora, Physopella and Cerotellium and their species on Leguminosae. Mycol. Res. 96:825-850.

Pandey, S. P., and Somssich, I. E. 2010. The role of WRKY transcription factors in plant immunity. Trends Plant Sci. 15:1-4.

Panthee, D. R., Yuan, J. S., Wright, D. L., Marois, J. J., Mailhot, D., and Stewart, C. N., Jr. 2007. Gene expression analysis in soybean in response to the causal agent of Asian soybean rust (Phakopsora pachyrhizi Sydow) in an early growth stage. Funct. Integr. Genomics 7:291301.

Panthee, D. R., Marois, J. J., Wright, D. L., Narvaez, D., Yuan, J. S., and Stewart, C. N., Jr. 2009. Differential expression of genes in soybean in response to the causal agent of Asian soybean rust (Phakopsora pachyrhizi Sydow) is soybean growth stage-specific. Theor. Appl. Genet. 118:359-370.

Parker, J. E., Holub, E. B., Frost, L. N., Falk, A., Gunn, N. D., and Daniels, M. J. 1996. Characterization of eds 1, a mutation in Arabidopsis suppressing resistance to Peronospora parasitica specified by several different RPP genes. Plant Cell 8:2033-2046.

Patil, V. S., Wuike, R. V., Thakare, C. S., and Chirame, B. B. 1997. Viability of uredospores of Phakopsora pachyrhizi Syd. at different storage conditions. J. Maharashtra Agric. Univ. 22:260-261.

Peart, J. R., Cook, G., Feys, B. J., Parker, J. E., and Baulcombe, D. C. 2002. An EDS1 orthologue is required for $N$-mediated resistance against Tobacco mosaic virus. Plant J. 29:569-579.

Quattrocchio, F., Verweij, W., Kroon, A., Spelt, C., Mol, J., and Koes, R. 2006. PH4 of Petunia is an R2R3 MYB protein that activates vacuolar acidification through interactions with basic-helix-loop-helix transcription factors of the anthocyanin pathway. Plant Cell 18:1274-1291.

Ray, J. D., Morel, W., Smith, J. R., Frederick, R. D., and Miles, M. R. 2009. Genetics and mapping of adult plant rust resistance in soybean PI 587886 and PI 587880A. Theor. Appl. Genet. 119:271-280.

Robatzek, S., and Somssich, I. E. 2002. Targets of AtWRKY6 regulation during plant senescence and pathogen defense. Genes Dev. 16:11391149 .

Rohde, A., Morreel, K., Ralph, J., Goeminne, G., Hostyn, V., De Rycke, R., Kushnir, S., Van Doorsselaere, J., Joseleau, J. P., Vuylsteke, M., Van Driessche, G., Van Beeumen, J., Messens, E., and Boerjan, W. 2004. Molecular phenotyping of the pal1 and pal2 mutants of Arabidopsis thaliana reveals far-reaching consequences on phenylpropanoid, amino acid, and carbohydrate metabolism. Plant Cell 16:2749-2771.

Rushton, P. J., Somssich, I. E., Ringler, P., and Shen, Q. J. 2010. WRKY transcription factors. Trends Plant Sci. 15:247-258.

Rusterucci, C., Aviv, D. H., Holt, B. F., Dangl, J. L., and Parker, J. E 2001. The disease resistance signaling components EDS1 and PAD4 are essential regulators of the cell death pathway controlled by LSD1 in Arabidopsis. Plant Cell 13:2211-2224.

Rytter, J. L., Dowler, W. M., and Bromfield, K. R. 1984. Additional alternative hosts of Phakopsora pachyrhizi, causal agent of soybean rust. Plant Dis. 68:818-819.

Sandhu, D., Tasma, I. M., Frasch, R., and Bhattacharyya, M. K. 2009. Systemic acquired resistance in soybean is regulated by two proteins orthologous to Arabidopsis NPR1. BMC Plant Biol. 9:105-119.

Sasaki, M., Yamamoto, Y., and Matsumoto, H. 1996. Lignin deposition induced by aluminum in wheat (Triticum aestivum) roots. Physiol. Plant. 96:193-198.

Schmutz, J., Cannon, S. B., Schlueter, J., Ma, J., Mitros, T., Nelson, W. Hyten, D. L., Song, Q., Thelen, J. J., Cheng, J., Xu, D., Hellsten, U., May, G.D., Yu, Y., Sakurai, T., Umezawa, T., Bhattacharyya, M. K., Sandhu, D., Valliyodan, B., Lindquist, E., Peto, M., Grant, D., Shu, S., Goodstein, D., Barry, K., Futrell-Griggs, M., Abernathy, B., Du, J., Tian, Z., Zhu, L., Gill, N., Joshi, T., Libault, M., Sethuraman, A., 
Zhang, X. C., Shinozaki, K., Nguyen, H. T., Wing, R. A., Cregan, P., Specht, J., Grimwood, J., Rokhsar, D., Stacey, G., Shoemaker, R. C., and Jackson, S. A. 2010. Genome sequence of the palaeopolyploid soybean. Nature 463:178-183.

Schneider, R. W., Hollier, C. A., and Whitam, H. K. 2005. First report of soybean rust caused by Phakopsora pachyrhizi in the continental United States. Plant Dis. 89:774-774.

Shoemaker, R. C., Keim, P., Vodkin, L., Retzel, E., Clifton, S. W. Waterson, R., Smoller, D., Coryveil, V., Khanna, A., and Erpelding, J. 2002. A compilation of soybean ESTs: Generation and analysis. Genome 45:329-338.

Silva, D. C., Yamanaka, N., Brogin, R. L., Arias, C. A., Nepomuceno, A. L., Di Mauro, A. O., Pereira, S. S., Nogueira, L. M., Passianotto, A. L., and Abdelnoor, R. V. 2008. Molecular mapping of two loci that confer resistance to Asian rust in soybean. Theor. Appl. Genet. 117:57-63.

Soria-Guerra, R. E., Rosales-Mendoza, S., Chang, S., Haudenshield, J. S., Padmanaban A., Rodriguez-Zas, S., Hartman, G. L., Ghabrial, S. A., and Korban, S. S. 2010. Transcriptome analysis of resistant and susceptible genotypes of Glycine tomentella during Phakopsora pachyrhizi infection reveals novel rust resistance genes. Theor. Appl. Genet. 120:1315-1333.

Stracke, R., Werber, M., and Weisshaar, B. 2001. The R2R3-MYB gene family in Arabidopsis thaliana. Curr. Opin. Plant Biol. 4:447-456.

Vance, C. P., Kirk, T. K., and Sherwood, R. T. 1980. Lignification as a mechanism of disease resistance. Annu. Rev. Phytopathol. 18:259-288.

van de Mortel, M., Recknor, J. C., Graham, M. A., Nettleton, D., Dittman, J. D., Nelson, R. T., Godoy, C. V., Abdelnoor, R. V., Almeida, A. M. R., Baum, T. J., and Whitham, S. A. 2007. Distinct biphasic mRNA changes in response to Asian soybean rust infection. Mol. PlantMicrobe Interact. 20:887-899.

Wang, H., Hao, J., Chen, X., Hao, Z., Wang, X., Lou, Y., Peng, Y., and Guo, Z. 2007. Overexpression of rice WRKY89 enhances ultraviolet B tolerance and disease resistance in rice plants. Plant Mol. Biol. 65:799-815.

Xiao, S., Calis, O., Patrick, E., Zhang, G., Charoenwattana, P., Muskett, P.,
Parker, J. E., and Turner, J. G. 2005. The atypical resistance gene, $R P W 8$, recruits components of basal defense for powdery mildew resistance in Arabidopsis. Plant J. 42:95-110.

Xu, P., Zhang, Y., Kang, L., Roossinck, M. J., and Mysore, K. S. 2006. Computational estimation and experimental verification of off-target silencing during posttranscriptional gene silencing in plants. Plant Physiol. 142:429-440.

Zabala, G., Zou, J., Tuteja, J., Gonzalez, D. O., Clough, S. J., and Vodkin, L. O. 2006. Transcriptome changes in the phenylpropanoid pathway of Glycine max in response to Pseudomonas syringae infection. BMC Plant Biol. 6:1-28.

Zhang, C., and Ghabrial, S. A. 2006. Development of Bean pod mottle virus based vectors for stable protein expression and sequence-specific virus induced gene silencing in soybean. Virology 344:401-411.

Zhang, C., Yang, C., Whitham, S. A., and Hill, J. H. 2009. Development and use of an efficient DNA-based viral gene silencing vector for soybean Mol. Plant-Microbe Interact. 22:123-131.

Zhang, C., Bradshaw, J. D., Whitham, S. A., and Hill, J. H. 2010. The development of an efficient multipurpose Bean pod mottle virus viral vector set for foreign gene expression and RNA silencing. Plant Physiol. 153:52-65.

Zhou, N., Tootle, T. L., Tsui, F., Klessig, D. F., and Glazebrook, J. 1998. PAD4 functions upstream from salicylic acid to control defense responses in Arabidopsis. Plant Cell 10:1021-1030.

Zhou, Q. Y., Tian, A. G., Zou, H. F., Xie, Z. M., Lei, G., Huang, J., Wang, C. M., Wang, H. W., Zhang, J. S., and Chen, S. Y. 2008. Soybean WRKY-type transcription factor genes, GmWRKY13, GmWRKY21, and GmWRKY54, confer differential tolerance to abiotic stresses in transgenic Arabidopsis plants. Plant Biotechnol. J. 6:486-503.

Zou, J., Rodriguez-Zas, S., Aldea, M., Li, M., Zhu, J., Gonzalez, D. O., Vodkin, L. O., DeLucia, E., and Clough, S. J. 2005. Expression profiling soybean response to Pseudomonas syringae reveals new defenserelated genes and rapid HR-specific down regulation of photosynthesis. Mol. Plant-Microbe Interact. 18:1161-1174. 